\title{
Record of the non-indigenous species Sternaspis aff. nana Zhadan, Tzetlin \& Salazar-Vallejo, 2017 (Annelida: Sternaspidae) in the Southwest Atlantic Ocean
}

\author{
Nykon Craveiro ${ }^{1,2}$ \& José Souto Rosa Filho $0^{1,3}$ \\ 1 Universidade Federal de Pernambuco (UFPE), Centro de Tecnologia e Geociências (CTG), Departamento de 0ceanografia, \\ Laboratório de Bentos. Recife, PE, Brasil. \\ ${ }^{2}$ ORCID: http://orcid.org/0000-0001-8296-5217. E-mail: nykoncraveiro@gmail.com (corresponding author) \\ ${ }^{3}$ ORCID: http://orcid.org/0000-0002-5496-7706.E-mail: souto.rosa@ufpe.br
}

\begin{abstract}
The introduction of non-indigenous marine species in new habitats is generally associated with ships arriving at ports, driven by species transported in ballast water and sediment and biofouling communities on ship hulls, drifting object and underwater surfaces in dock areas. The present paper reports the record of the specie Sternaspis aff. nana in the Atlantic Ocean, discussing its possible conservation status and method of arrival to Brazil. Sediments samples were collected in the external area (11 m depth) of the Suape Harbor (Brazil) in February 2018. Two individuals of Sternaspis aff. nana were recorded, representing the first record of this species in the Southwest Atlantic 0cean. The way S. aff. nana arrived in Brazilian waters cannot be easily determined, the short-lived lecithotrophic larvae of sternaspids suggest that the specimens found in Suape have arrived in ballast sediment. An increase in trade between Brazil and Asian countries since the 2000s has led to that more ships coming from China having arrived in Brazilian harbors. The arrival of S. aff. nana, originally described in the South China Sea, in the Suape harbor area may have resulted from this intense movement of ships between China and Brazil.
\end{abstract}

Keywords. Polychaeta; Exotic species; Northeastern Brazil; Shipping activities; Ballast sediment.

\section{INTRODUCTION}

The introduction of non-indigenous species (NIS) may cause significant ecological impacts (Carlton, 1999; Çinar, 2013), being these introductions generally associated with ships arriving at ports (Bumbeer \& Rocha, 2016), driven by species associated with ballast water/sediment and biofouling communities on ship hulls, drifting object and underwater surfaces in dock areas (Keppel et al., 2015). Benthic invertebrates have a wide variety of life histories (Godwin, 2003) and many have long larval stages, favoring transport of these species between areas separated by thousands of kilometers (Townsend et al., 2006; Çinar, 2013). Even benthic species without planktonic stage or with short-lived larvae can efficiently disperse using different ways of transportation (Jablonsky \& Lutz, 1983; Winston, 2012), such as drifting, rafting, hitchhiking, creeping, and hopping (Thiel \& Haye, 2006; Winston, 2012).

The number of NIS has increased concomitantly with the increase of transoceanic transport (Keppel et al., 2015), since the shipping transport is considered the main vector of marine species invasions worldwide (Gollasch et al., 2002; Çinar, 2013; Gollasch \& David, 2019) and it can lead to a profound alteration of the diversity and structure of coastal communities (Carlton, 1999; Hamer, 2002; Çinar, 2013). Carlton (1999) estimated that a $17^{\text {th }}$ century wooden vessel could easily have transported 150 species of marine protists, invertebrates and plants per voyage, a number that may be rivalled or exceeded by a $21^{\text {th }}$ century ship due to faster transit times and larger hull sizes. Ahyong et al. (2020) recorded more than 1.737 marine alien species globally. Most were probably introduced by ship movements (ballast tanks and/ or biofouling) (Ruiz, 1997; Godwin, 2003; Seebens et al., 2013). More than 292 species of marine polychaetes, belonging to 164 genera, have been reported as NIS globally, most of them Syllidae Grube, 1850, Spionidae Grube, 1850, Sabellidae Latreille, 1825, Serpulidae Rafinesque, 1815 and Nereididae Blainville, 1818 (Çinar, 2013). Among the approximately 46 polychaeta species classified as NIS in Brazil (Rodrigues et al., 2020), eight are invasive exotic species (I3N, 2018). To date, 
non-indigenous Sternaspidae has not been recorded on the Brazilian coast, but in the UK (Townsend et al., 2006; Shelley et al., 2008), India (Jose et al., 2014) and Egypt (Abdelnaby, 2020), Sternaspis scutata (Ranzani, 1817) has been recorded as a non-native or invasive polychaeta.

Sternaspids are polychaetes with a peanut-shaped body and a characteristic stiff ventral shield (Sendall \& SalazarVallejo, 2013). Up to date, 44 species of Sternaspidae Carus, 1863 have been recorded in marine waters worldwide (Sendall \& Salazar-Vallejo, 2013; Díaz-Díaz \& Rozbaczylo, 2017; Fiege \& Barnich, 2020). The family has four genera: Sternaspis Otto, 1820, Caulleryaspis Sendall \& SalazarVallejo, 2013, Petersenaspis Sendall \& Salazar-Vallejo, 2013 and Mauretanaspis Fiege \& Barnich, 2020, distinguished via characteristics of the shield, introvert hooks and the number of segments of the anterior portion of abdomen (Sendall \& Salazar-Vallejo, 2013; Drennan et al., 2019).

Common and occurring in all oceans, sternaspids are motile, subsurface deposit feeders and are observed in association with a great variety of substrates ranging from coarse sand to soft mud (Sendall \& Salazar-Vallejo, 2013; Jumars et al., 2015; Díaz-Díaz \& Rozbaczylo, 2017). The high adaptive capacity of sternaspids can favor introductions of these polychaetes in non-native environments, but only Sternaspis scutata has already been registered as invasive especie (Townsend et al., 2006) in European waters.

Only Petersenaspis capillata (Nonato, 1966) has been recorded in Brazil, occurring from Pernambuco to Rio Grande do Sul, in muddy bottoms ranging from shallow waters (estuaries and beaches) to the deep sea (Amaral et al., 2013). Sternaspis nana Zhadan et al., 2017 was recently described in the South China Sea. We present the record of Sternaspis aff. nana in the Southwest Atlantic Ocean, discussing its possible 'conservation status' and method of arrival in Brazil.

\section{MATERIAL AND METHODS}

Sediments samples were collected in the external area of the Suape Harbor (Pernambuco, Brazil $08^{\circ} 23^{\prime} 37.6^{\prime \prime} \mathrm{S} 34^{\circ} 57^{\prime} 19.3^{\prime \prime} \mathrm{W}$ ) in February 2018. Samples were collected using a Van Veen Grab at a depth of $15 \mathrm{~m}$. After collection, samples were fixed in saline formalin $4 \%$ and thereafter the polychaetes were identified following Zhadan et al. (2017). After identification, all specimens were deposited in the "Museu de Oceanografia Prof. Petrônio Alves Coelho (MOUFPE)" at Universidade Federal de Pernambuco, Recife, Brazil.

\section{RESULTS}

\section{Systematics \\ Order Terebellida Rouse \& Fauchald, 1997 \\ Family Sternaspidae Carus, 1863 Genus Sternaspis Otto, 1820 \\ Sternaspis aff. nana Zhadan et al., 2017}

(Figs. 1-3)

Sternaspis nana Zhadan et al., 2017: 79-82, fig. 3-5; Salazar-Vallejo, 2017: 4.

\section{Examined material}

Two specimens collected at the external area of the Suape Harbor, Pernambuco, Brazil $\left(08^{\circ} 23^{\prime} 37.6^{\prime \prime} S\right.$, $\left.34^{\circ} 57^{\prime} 19.3^{\prime \prime} \mathrm{W}\right)$, mud substrate, $15 \mathrm{~m}$ depth, 16-II-2018, MOUPFE 003.

\section{Description}

The morphology of the two specimens agree with the descriptions of Sternaspis nana by Zhadan et al. (2017), but due to the impossibility of observing the gametes due to the small size of the specimens, the morphological differences of the shield and the amount of papillae in the species found here in Brazil, we classify the specimens as Sternaspis aff. nana. Our specimens seem to be more rugose than the type specimens and the posterior shield margin has a round projection, as opposed to having a sharp one, or none as in the type species (Zhadan et al., 2017).

Complete specimens with 26 segments without clear borders (Body: $2.20 \mathrm{~mm}$ long, $0.82 \mathrm{~mm}$ wide). Body hourglass-shaped, introvert narrower than abdomen, constriction between segments 5 and 6 . Body wall semi-transparent; introvert colorless, abdomen creamish-white with abundant minute papillae evenly distributed, both dorsally and ventrally, and papillae cirriform (Fig. 1C). Intestine and ventral nerve are visible through body wall (Figs. 1A-B, 2B).

First three chaetigers with 13 falcate hooks per bundle, not subdistally expanded, hooks transparent (Fig. 3). Genital papilla small, digitate, protruding ventrally from sixth chaetiger (Fig. 1A, C). Pre-shield region with 7 segments, with 1-2 fine capillary chaetae laterally in some segments (Fig. 2A).

Table 1. Main morphological features of Sternaspis aff. nana, S. africana, S. papillosa. Legend: BP (Body papillae), IH (Introvert Hooks), CBW (Chaetae of body wall), S (Shield), LSC (Laterial shield chaetae), PSC (Posterior shield chaetae), PC (Peg Chaetae).

\begin{tabular}{|c|c|c|c|c|c|c|c|}
\hline Species & BP & IH & CBW & $S$ & LSC & PSC & PC \\
\hline Sternaspis aff. nana & $\begin{array}{l}\text { Very small not arranged in series } \\
\text { and long cirriform }\end{array}$ & 13 & Fine capillary chaetae & $\begin{array}{l}\text { Ribs and concentric lines not visible. Without } \\
\text { papillae and no sediment particles attached. }\end{array}$ & 8 in oval pattern & 5-6 slightly curved pattern & Present \\
\hline Sternaspis africana & Minute, rows of cluster & $15-20$ & Fine capillary chaetae & $\begin{array}{l}\text { Ribs and concentric lines barely visible. Without } \\
\text { papillae and no sediment particles attached. }\end{array}$ & 9 in oval pattern & 5 slightly curved pattern & Present \\
\hline Sternaspis papillosa & $\begin{array}{l}\text { Simple cirriform papillae forming } \\
\text { irregular transverse rows }\end{array}$ & 16 & Absent & $\begin{array}{l}\text { Ribs and concentric lines barely visible. Sediment } \\
\text { particles adhered; covered by fine papillae. }\end{array}$ & 9 in oval pattern & 5 in linear pattern & Present \\
\hline
\end{tabular}



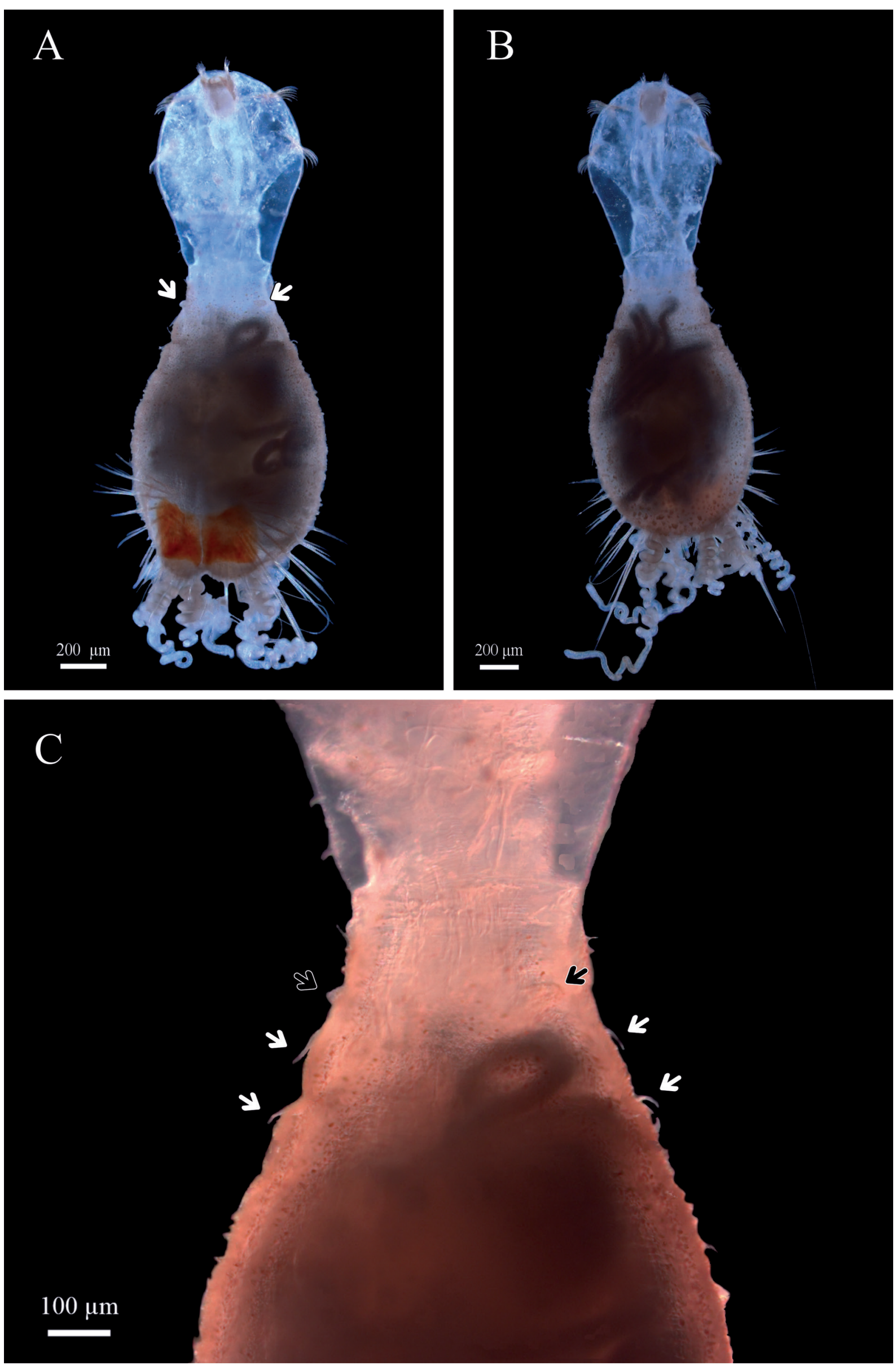

Figure 1. Sternaspis aff. nana collected in Suape Harbor (Pernambuco, Brazil). (A) Ventral view. White arrows showing genital papillae; (B) Dorsal view; (C) Detailed ventral view of abdomen (pre-shield). Black arrows showing long filiform papillae and white arrows showing genital papillae. 

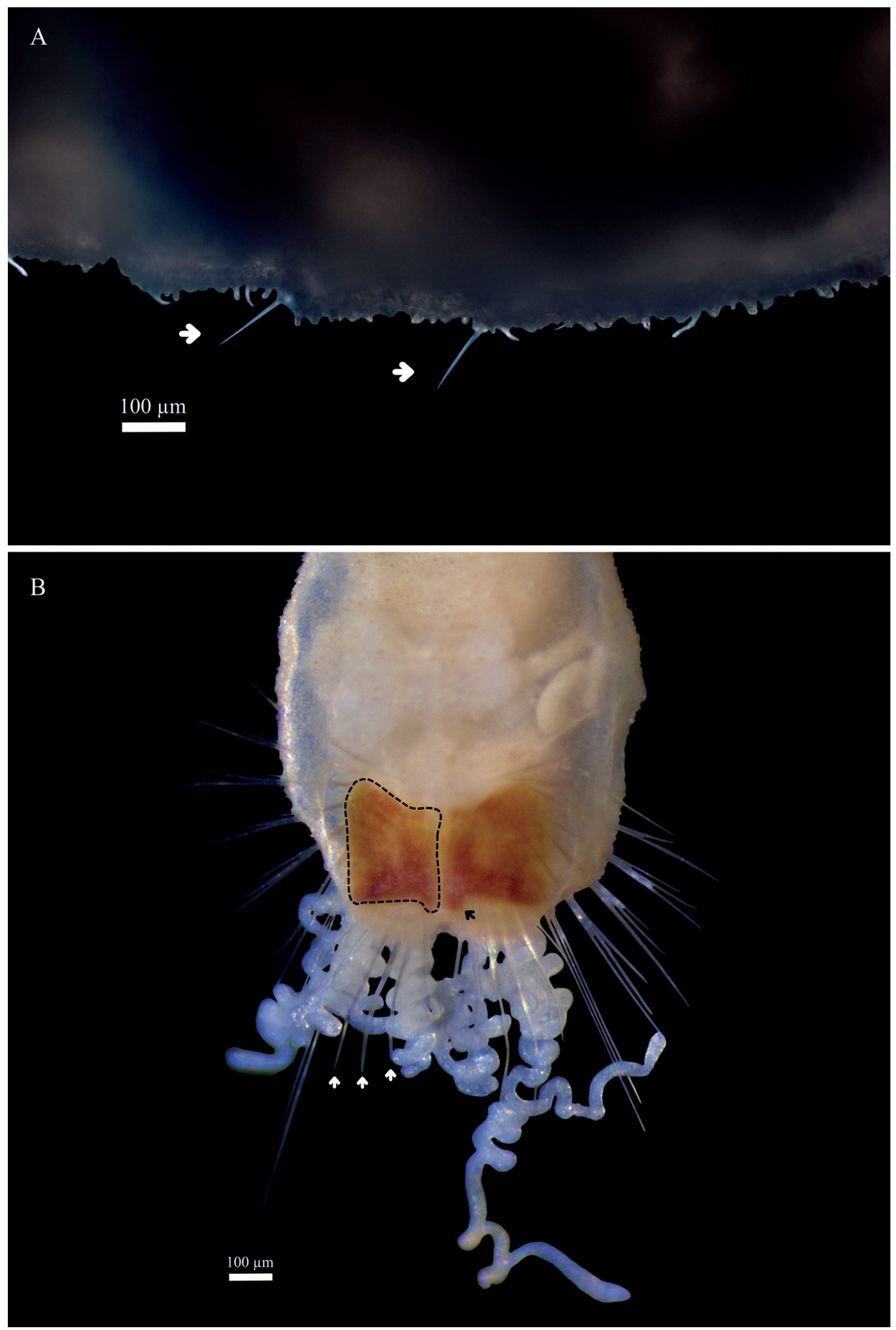

Figure 2. Sternaspis aff. nana collected in Suape Harbor (Pernambuco, Brazil). (A) Detailed view of the margin of abdomen wall. White arrows showing pre-shield capillary chaetae; (B) Ventrocaudal shields. Black dotted showing shield plates nearly square. White arrows showing fascicles containing only one thick chaeta each, black arrow showing fan corners extended. 
Ventrocaudal shield soft, smooth, papillae not observed and no sediment particles attached. Left shield plate $0.21 \mathrm{~mm}$ long, $0.25 \mathrm{~mm}$ wide. Shield plates nearly square. Ribs and concentric lines not visible. (Fig. 2B). No visible borders between lateral plates and fan (Fig. 2B). Anterior keels visible, suture well-defined, visible throughout shield (Fig. 2B).

Bundles of shield chaetae with eight lateral shield chaetae, ovally arranged and five posterior fascicles each containing only one thick chaeta, slightly curved (Fig. 2B). Peg-chaetae not observed. Branchial filaments arranged in discrete branchial plates.

\section{Distribution}

Type locality: Pacific Ocean - Nha Trang Bay, South China Sea (15-40 m depth). New occurrence: Atlantic Ocean - Suape Harbor Area, Pernambuco, Brazil (15 m depth).

\section{Remarks}

On the Brazilian coast, only one species of Sternaspidae has been recorded to date, Petersenaspis capillata (Nonato, 1966) [= Sternaspis capillata Nonato, 1966], which is native and found in Brazilian waters (Nonato, 1966). The morphology of our specimens is similar to the original description of Sternaspis nana by Zhadan et al. (2017) and resembles S. papillosa Zhadan et al., 2017 and S. africana Augener, 1918. Sternaspis aff. nana markedly differs from these species by combined features related to hooks of introvert, papillae pattern and ventral shield characteristics.

In S. aff. nana there are 13 falcate hooks per bundle in the introvert chaetigers, while the number of falcate hooks per bundle is 16 in S. papillosa and 15-20 in S. africana. Sternaspis aff. nana has abundant micropapillae and regular rows of long cirriform papillae along the body. In S. papillosa digitiform papillae are organized in more or less regular transverse rows, and in S. africana minute papillae are densely present on segments 7 and 8, but evenly spaced in other segments. Ventral shield in S. aff. nana is without ribs and papillae, usually without concentric lines, with eight lateral shield chaetae in oval pattern, and six posterior shield chaetae consisting of a single thick chaeta in slightly curved pattern. In S. papillosa, ventral shield is with underdeveloped ribs and concentric lines, covered by fine papillae, with nine lateral shield chaetae in oval pattern, and five posterior shield chaetae in oval pattern; in S. Africana, ventral shield is with ribs and concentric lines barely visible, without papillae, with nine lateral shield chaetae in oval pattern, and five posterior shield chaetae in slightly curved pattern. The morphological features remarks are resumed in Table 1.

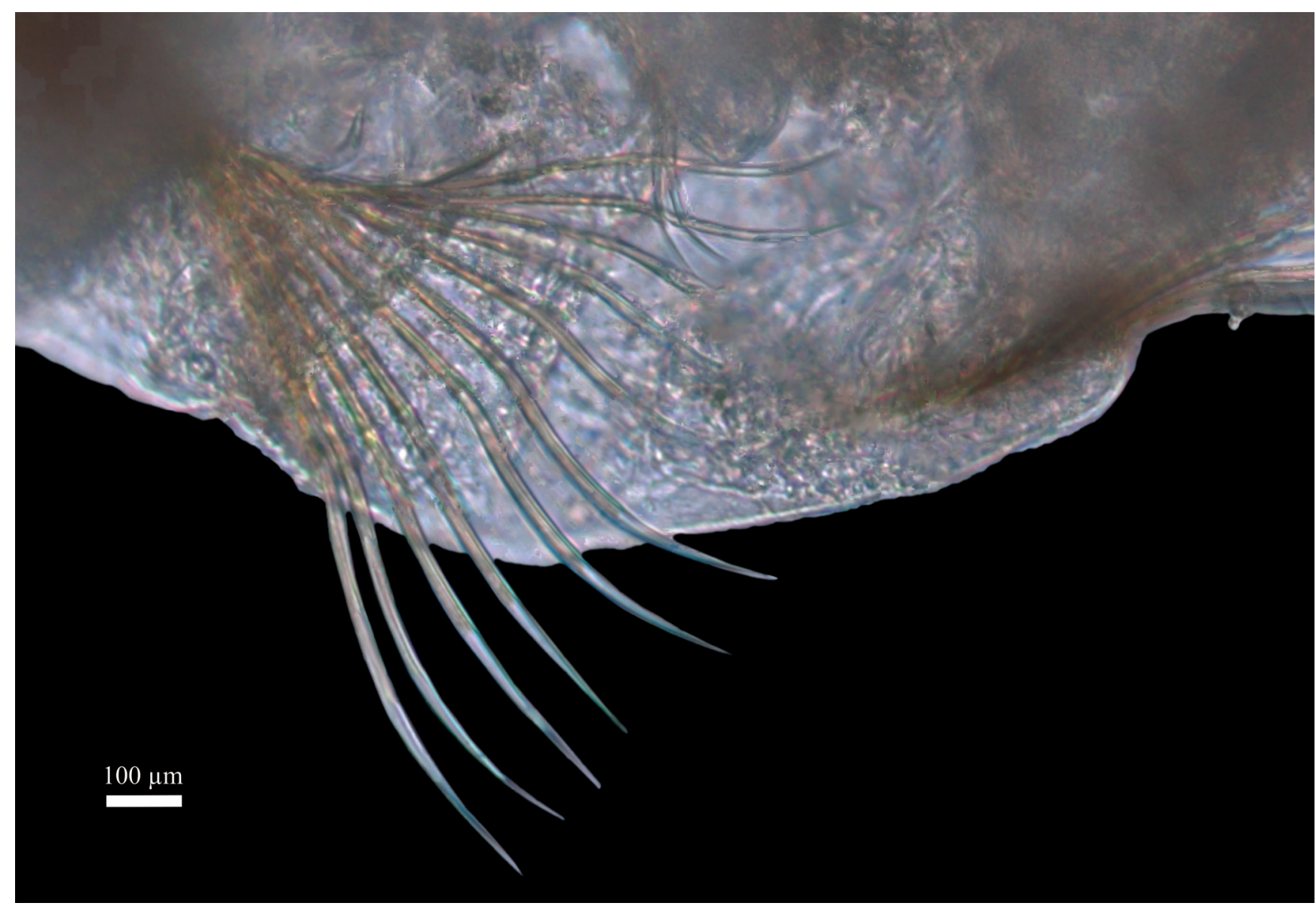

Figure 3. Sternaspis aff. nana collected in Suape Harbor (Pernambuco, Brazil). Detail of Introvert hooks of the first chaetiger. 


\section{DISCUSSION}

The polychaete Sternaspis nana was originally described in the South China Sea at depths ranging from $15-40 \mathrm{~m}$ in muddy substrates (Zhadan et al., 2017). This is the first record of this species on the Brazil coast, expanding the known geographic distribution of S. aff. nana to the Southwest Atlantic Ocean and indicating the occurrence of a new non-indigenous species (NIS) for the Brazilian waters.

Studies have shown that the occurrence of some organisms could not be explained by the natural distribution of larvae and/or adults (Farrapeira et al., 2011). The shipping industry, via ballast water and sediments, anchoring, and biofouling, may be the main vector of marine species introduction, including polychaetes (Neves \& Rocha, 2008; Çinar, 2013; Gollasch \& David, 2019). Introduction of NIS by commercial shipping typically results in harbors becoming hotspots of biotic invasion (Wasson et al., 2001; Hewitt et al., 2004). Globally, about 1.697 species are classified as alien species, 78 species with uncertain origin and 121 species with unknown origin (Ahyong et al., 2020). In Brazil, around 46\% of recorded marine NIS were introduced by ballast water/sediments and/or biofouling (Lopes et al., 2009). Farrapeira et al. (2011) cite that introduction by hull biofouling has been proven for 228 species of marine invertebrates. Polychaetes such as Branchiomma luctuosum (Grube, 1870) (original distribution: Red Sea; Nogueira et al., 2006; Oricchio et al., 2019), Polydora cornuta Bosc, 1802 (original distribution: Western Atlantic and Caribbean; Neves \& Rocha, 2008), Pseudopolydora diopatra Hsieh, 1992 (original distribution: Western Pacific - Taiwan; Silva \& Barros, 2011), Hydroides elegans (Haswell, 1883) (original distribution: Australasia and the Indian Ocean; Schwan et al., 2016; Oricchio et al., 2019) and Trochochaeta japonica Imajima, 1989 (original distribution: Pacific North - Japão; Radashevsky et al., 2018) are already known to have been introduced to the Brazilian coast in ship ballast tanks and/or biofouling.

The way S. aff. nana arrived in Brazilian waters cannot be easily determined. In general, species with larvae that actively seek food (planktotrophic larvae) disperse easily and may invade new areas, although species with lecithotrophic development (that do not need external food) have also been registered as invaders (Jablonsky \& Lutz, 1983). Given that sternaspids larvae are short-lived and lecithotrophic (Strathmann, 1987), generally settling in less than two days (Rouse \& Pleijel, 2001), and the great distance from China to Brazil (four to seven weeks travel), the species probably did not arrive in Suape Harbor as larvae, but as juveniles or adults, however it was not possible to observe the gametes in the specimens due to their small size, and thus estimate their ages.

As discussed by Winston (2012) invertebrates with direct development (without planktonic stage) or with short-lived larvae (yolky nonfeeding larvae) can disperse using different ways such as drifting, rafting, hitchhiking, creeping, and hopping. Sternaspis aff. nana (larvae or adults) may have arrived in Suape in ballast tanks of ships.
When a vessel takes on ballast water, sediment and the associated benthic organisms, resting stages can be taken onboard (Hamer, 2002; Gollasch et al., 2002; Gollasch \& David, 2019). Suspended sediment settles to the tank bottom, providing suitable habitat for benthic organisms (Gollasch \& Leppakoski 1999; Briski et al., 2010, 2011). Lucas et al. (1999) found volume of sediments (mostly mud) varying from a few $\mathrm{cm}$ to more than $30 \mathrm{~cm}$ depth in ballast tanks. Williams et al. (1988) recorded 21 taxa (crustaceans and polychaetes) in ballast sediments in ships sailing between Japan and Australia. Macroinvertebrates were found by Briski et al. (2012) in ballast sediments of $10.4 \%$ of transoceanic ships in Canada harbors, with an average density of 2.8 individuals per tank when present. Considering that $S$. aff. nana occurs in muddy bottoms, it is probable that the dispersion to the Suape Habor occurred in ballast sediments.

The Suape Harbor Complex is one of Brazil's largest and most important harbors for cargo and container operation, receiving more than 1.000 ships annually from 160 countries (SUAPE, 2019). Between 2013 and 2017, cargo volume in the Suape Harbor Complex increased by $73.3 \%$ for long-haul vessels, with origins and destinations to the United States, Argentina, Germany, Holland, Mexico, China and Kuwait (MTPA, 2018). In recent years, the trade between Brazil and Asia has increased; China has become Brazil's primary trading partner (Moore, 2009; The World Bank, 2014) and China's relative share in Brazilian foreign trade increased from only $2 \%$ in 2000 to close to 20\% in 2015 (Dantas \& Jabbour, 2016). This increase in trade has led to more ships from China arriving in Brazilian harbors, favoring the introduction of Chinese marine species. The arrival of Sternaspis aff. nana, originally described in the South China Sea, into the Suape harbor area is likely to be a result of this intense movement of ships between China and Brazil.

\section{ACKNOWLEDGMENTS}

We would like to thank the Diretoria de Meio Ambiente e Sustentabilidade de SUAPE - Complexo Industrial Portuário Governador Eraldo Gueiros and DBF Planejamento e Consultoria for supplying the material used and providing the necessary logistic support for this study. The authors would like thanks to Section Editor and Journal Editor for supports, and reviewers that provided valuable comments and suggestions. We also thank Dr. Sergio I. Salazar-Vallejo for valuable comments, contributions and exchanging information regarding the specimen. We also thank Dr. Anna E. Zhadan for exchanging information regarding the specimen. We are also grateful to Claudeilton Santana for the help in obtaining photographs.

\section{AUTHORS' CONTRIBUTION}

N.C.: research conceptualization, data collection, data analysis and interpretation, roles/writing - original draft; 
writing - review \& editing. J.S.R.F.: research conceptualization, data analysis and interpretation, roles/writing original draft; writing - review \& editing.

\section{FUNDING DECLARATION}

Authors received no specific funding for this work.

\section{CONFLICT/DECLARATION OF INTEREST}

None.

\section{ETHICS AND PERMITS}

All research pertaining to this article did not require any research permits.

\section{REFERENCES}

Abdelnaby, A.F. 2020. First record of Sternaspis scutata (Polychaeta, Sternaspidae) in Egyptian waters. Egyptian Journal of Aquatic Biology and Fisheries, 24(2), 317-326. DOI

Ahyong, S.; Costello, M.J.; Galil, B.S.; Gollasch, S.; Hutchings, P.; Katsanevakis, S.; Lejeusne, C.; Marchini, A.; Occhipinti, A.; Pagad, S.; Poore, G.; Rius, M.; Robinson, T.B.; Sterrer, W.; Turon, X.; Willan, R.C. \& Zhan, A. 2020. World Register of Introduced Marine Species (WRiMS). Available: http://www. marinespecies.org/introduced. Access: 18/09/2020.

Amaral, A.C.Z.; Nallin, S.A.H.; Steiner, T.M.; Forroni, T.0. \& Gomes, D.F. 2013. Catálogo das espécies de Annelida Polychaeta do Brasil. Available: http:// www.ib.unicamp.br/museu zoologia/files/lab museu zoologia/ Catalogo Polychaeta Amaral et al 2012.pdf. Access: 01/09/2020.

Augener, H. 1918. Polychaeta. In: Beiträge zur Kenntnis des Meeresfauna Westafrikas, Hamburg, L. Friederischen. v. 2, pt. 2, p. 2, p. 67-625, 6 pl.

Bosc, L.A.G. 1802. Histoire naturelle des vers, contenant leur déscription et leurs moeurs, avec figures dessinées d'après nature. Paris, Deterville. 3v.

Briski, E.; Bailey, S.A. \& Maclsaac, H.J. 2011. Invertebrates and their dormant eggs transported in ballast sediments of ships arriving to the Canadian coasts and the Laurentian Great Lakes. Limnology and Oceanography, 56: 1929-1939. DOI

Briski, E.; Bailey, S.A. \& Maclsaac, H.J. 2012. Invasion risk posed by macroinvertebrates transported in ships' ballast tanks Elizabeta. Biological Indicators, 14(9): 1843-1850. DOI

Briski, E.; Bailey, S.A.; Cristescu, M.E. \& Maclsaac, H.J. 2010. Efficacy of 'saltwater flushing' in protecting the Great Lakes from biological invasions by invertebrate eggs in ships' ballast sediment. Freshwater Biology, 55(11): 2414-2424. D0I

Bumbeer, J. \& Rocha, R.M. 2016. Invading the natural marine substrates: a case study with invertebrates in South Brazil. Zoologia, 33(3): 1-7, e20150211. DO

Carlton, J.T. 1999. The scale and ecological consequences of biological invasions in the world's oceans. In: Sandlund, 0.T.; Schei, P.J. \& Viken, A. Invasive species and biodiversity management. Dordrecht, Kluwer Academic Publishers. p. 195-212.

Carus, J.V. 1863. Vermes. In: Peters, W.C.H.; Carus, J.V. \& Gerstäcker, C.E.A. Handbuch der Zoologie. Leipzig, Wilhelm Engelmann. v. 2, p. 422-484. http://biodiversitylibrary.org/page/1092677.
Çinar, M.E. 2013. Alien polychaete species worldwide: current status and their impacts. Journal of the Marine Biological Association of the United Kingdom, 93(5): 1257-1278. DOI

Complexo Industrial Portuário Governador Eraldo Gueiros (SUAPE). 2019. The Port of the Future. Available: http://www.suape.pe.gov.br/en/port/theport-of-the-future. Access: 01/05/2020.

Dantas, A.T. \& Jabbour, M.K. 2016. Brazil and China: an assessment of recent trade relations. Economics of Agriculture, 63(1): 313-322. D0I

Díaz-Díaz, 0. \& Rozbaczylo, N. 2017. Sternaspis chilensis n. sp., a new species from austral Chilean channels and fjords (Annelida, Sternaspidae). Zootaxa, 4254(2): 269-276.

Drennan, R.; Wiklund, H.; Rouse, G.W.; Georgieva, M.N.; Wu, X.; Kobayashi, G.; Yoshino, K. \& Glover, A.G. 2019. Taxonomy and phylogeny of mud owls (Annelida: Sternaspidae), including a new synonymy and new records from the Southern 0cean, North East Atlantic Ocean and Pacific Ocean: challenges in morphological delimitation. Marine Biodiversity, 49: 2659-2697.

Farrapeira, C.M.R.; Tenório, D.O. \& Amaral, F.D. 2011. Vessel biofouling as an inadvertent vector of benthic invertebrates occurring in Brazil. Marine Pollution Bulletin, 62(4): 832-839.

Fiege, D. \& Barnich, R. 2020. A new genus and species of Sternaspidae (Annelida: Polychaeta) from the deep eastern Atlantic. European Journal of Taxonomy, 699: 1-13.

Godwin, L.S. 2003. Hull fouling of maritime vessels as a pathway for marine species invasions to the Hawaiian Islands. Biofouling, 19: 123-131. DOI

Gollasch, S. \& David, M. 2019. Ballast Water: Problems and Management. In: Sheppard, C. World Seas: An Environmental Evaluation. Academic Press, New York, 237-250.

Gollasch, S. \& Leppakoski, E. 1999. Initial risk assessment of alien species in Nordic coastal Waters. Copenhagen, Nordic Council of Ministers. 246p.

Gollasch, S.; Macdonald, E.; Belson, S.; Botnen, H.; Christensen, J.; Hamer, J.; Houvenaghel, G.; Jelmert, A.; Lucas, I.; Masson, D.; McCollin, T.; Olenin, S.; Persson, A.; Wallentinus, I.; Wetsteyn, B. \& Wittling, T. 2002. Life in ballast tanks. In: Leppäkoski E.; Gollasch, S. \& Olenin, S. Invasive aquatic species of Europe: distribution, impacts and management. Dordrecht, Kluwe., p. 217-231.

Grube, E. 1870. Beschreibungen neuer oder weniger bekannter von Hrn. Ehrenberg gesammelter Anneliden des rothen Meeres. Monatsberichte der Koniglichen Preussischen Akademie der Wissenschaften Berlin, 1869: 484-521.

Hamer, J.P. 2002. Ballast Tank Sediments. In: Leppäkoski E.; Gollasch S. \& Olenin S. (Eds.). Invasive Aquatic Species of Europe. Distribution Impacts and Management. Dordrecht, Springer. p. 232-257. D0I

Haswell, W.A. 1883. On some new Australian tubicolous Annelids. Proceedings of the Linnean Society of New South Wales, 7: 633-638.

Hewitt, C.L.; Campbell, M.L.; Thresher, R.E.; Martin, R.B.; Boyd, S.; Cohen, B.F.; Currie, D.R.; Gomon, M.F.; Keough, M.J.; Lewis, J.A.; Lockett, M.M.; Mays, N.; McArthur, M.A.; O'Hara, T.D.; Poore, G.C.B.; Ross, D.J.; Storey, M.J.; Watson, J.E. \& Wilson, R.S. 2004. Introduced and cryptogenic species in port Phillip bay, Victoria, Australia. Marine Biology, 144(1): 183-202. D01

Hsieh, H.L. 1992. Pseudopolydora diopatra, a new species (Polychaeta: Spionidae) from Taiwan. Proceedings of the Biological Society of Washington, 105(3): 630-635.

Invasives Information Network (I3N) 2018. Base de dados nacional de espécies exóticas invasoras - Brasil. Available: http://i3n.institutohorus.org.br/ www. Access: 01/05/2019.

Imajima, M. 1989. A new species of Trochochaeta (Polychaeta, Trochochaetidae) from Japan. Bulletin of the National Science Museum, Tokyo, Series A (Zoology), 15(3): 139-146.

Jablonsky, D. \& Lutz, R.A. 1983. Larval ecology of marine benthic invertebrates: Paleobiological implications. Biological Reviews, 58: 21-89. DOI 
Jose, H.P.M.; Muthuvelu, S.; Sivaraj, S. \& Murugesan, P. 2014. A Note on the Occurrence of Sternaspis scutata (Renier 1807) - A Sternaspid Polychaete from Sundarban Mangroves, West Bengal, India. Journal of the Bombay Natural History Society (JBNHS), 111(1): 62-64. D0I

Jumars, P.A.; Dorgan, K.M. \& Lindsey, S.M. 2015. Diet of worms emended: an update of polychaete feeding guilds. Annual Review of Marine Sciences, 7: 497-520. DOI

Keppel, E.; Tovar-Hernández, M.A.; Ruiz, G. 2015. First record and establishment of Branchiomma coheni (Polychaeta: Sabellidae) in the Atlantic Ocean and review of non-indigenous species of the genus. Zootaxa, 4058: 499-518.

Lopes, R.; Coradin, L.; Pombo, V.B. \& Cunha, D.R. 2009. Informe sobre as espécies exóticas invasoras marinhas no Brasil. Brasília, MMA

Lucas, I.A.N.; McCollin, T.A. \& Hamer, J.P. 1999. Marine organism in ships ballast water. Report to Ministry for Agriculture, Fisheries and Food, UK.

Ministério dos Transportes, Portos e Aviação Civil (MTPA). 2018. Planejamento portuário. Available: http://www.transportes.gov.br/images/SNP/ planejamento portuario/planos mestres/versao preliminar/vp25v2. pdf. Access: 01/06/2019.

Moore, M. 2009. China overtakes the US as Brazil's largest trading partner. The Telegraph, 9 May 2009.

Neves, C.S. \& Rocha, R.M. 2008. Introduced and cryptogenic species and their management in Paranaguá Bay, Brazil. Brazilian Archives of Biology and Technology, 51(3): 623-633. DOI

Nogueira, J.M.M.; Rossi, M.C.S. \& Lopez, E. 2006. Intertidal species of Branchiomma Kölliker and Pseudobranchiomma Jones (Polychaeta: Sabellidae: Sabellinae) occurring on rocky shores along the state of São Paulo, Southeastern Brazil. Zoological Studies, 45(4): 586-610.

Nonato, E.F. 1966. Sternaspis capillata sp. n. (Annelida, Polychaeta). Boletim do Instituto Oceanográfico da Universidade de São Paulo, 15(1):79-83.DOI

Oricchio, F.T.; Marques, A.C.; Hajdu, E.; Pitombo, F.B.; Azevedo, F.; Passos, F.D.; Vieira, L.M.; Stampar, S.N.; Rocha, R.M. \& Dias, G.M. 2019. Exotic species dominate marinas between the two most populated regions in the southwestern Atlantic Ocean. Marine Pollution Bulletin, 146: 884-892. D0I

0tto, A.G. 1820. De Sternaspide thalassemoideo et Siphostomate diplochaito vermibus duobus marinis. Vratislaviae, Typis Universitatis.

Radashevsky, V.I.; Rizzo, A.E. \& Peixoto, A.J. 2018. First record of Trochochaeta japonica (Annelida: Spionidae) in Brazil with identification key to species of the genus. Zootaxa, 4462(4): 566-578.

Ranzani, C. 1817. Descrizione di una nuova specie del genere Thalassema. Opuscoli scientifica, 2(112): 12-13.

Rodrigues, A.R.; Skinner, L.F. \& Brasil, A.C.D.S. 2020. Do Morphological Similarities and human-induced dispersal explain the non-native occurrence of Serpulidae (Annelida) in Southwest Atlantic? Taxonomic detailing is the key. Papéis Avulsos de Zoologia, 60(5): 1-15, e20206005. DOI

Rouse, G.W. \& Fauchald, K. 1997. Cladistics and polychaetes. Zoologica Scripta, 26(2): 139-204.

Rouse, G.W. \& Pleijel, F. 2001. Polychaetes. Oxford, Oxford University Press.
Ruiz, G.M.; Carlton, J.T.; Grosholz, E.D. \& Hines, A.H. 1997. Global invasions of marine and estuarine habitats by non-indigenous species: mechanisms, extent, and consequences. American Zoologist, 37(6): 619-630. D0I

Salazar-Vallejo, S.I. 2017. Six new tropical sternaspid species (Annelida, Sternaspidae) with keys to identify genera and species. Zoological Studies, 56: 32(1-16). D0I

Schwan, I.D.S.; Brasil, A.C.D.S.; Neves, D. \& Dias, G.M. 2016. The invasive worm Hydroides elegans (Polychaeta-Serpulidae) in southeastern Brazil and its potential to dominate hard substrata. Marine Biology Research, 12(1): 96-103.

Seebens, H.; Gastner, M.T. Blasius, B. \& Courchamp, F. 2013. The risk of marine bioinvasion caused by global shipping. Ecology letters, 16(6): 782-790. DOI

Sendall, K. \& Salazar-Vallejo, S.I. 2013. Revision of Sternaspis 0tto, 1821 (Polychaeta, Sternaspidae). ZooKeys, 286: 1-74. D0I

Shelley, R.; Widdicombe, S.; Woodward, M.; Stevens, T.; McNeill, C.L.; \& Kendall, M.A. 2008. An investigation of the impacts on biodiversity and ecosystem functioning of soft sediments by the non-native polychaete Sternaspis scutata (Polychaeta: Sternaspidae). Journal of Experimental Marine Biology and Ecology, 366(1-2), 146-150. D01

Silva, E.C. \& Barros, F. 2011. Macrofauna bentônica introduzida no Brasil: Lista de espécies marinhas e dulciaquícolas e distribuição atual. Oecologia Australis, 2(15): 326-344. DOI

Strathmann, M.F. 1987. Phylum Annelida, Class Polychaeta. In: Strathmann, M.F. Reproduction and Development of Marine Invertebrates of the Northern Pacific Coast: Data and Methods for the Study of Eggs, Embryos, and Larvae. Seatle, University of Washington Press. p. 138-195.

TheWorld Bank. 2014. Implications of a changing China for Brazil:anew window of opportunity? (English). Washington, DC: World Bank Group. Available: http://documents.worldbank.org/curated/en/794561468017425088/ Implications-of-a-changing-China-for-Brazil-a-new-window-ofopportunity. Access: 01/06/2020.

Thiel, M. \& Haye, P.A. 2006. The ecology of rafting in the marine environment. III. Biogeographical and evolutionary consequences. Oceanography and Marine Biology: An Annual Review, 44: 323-429.

Townsend, M.; Worsfold, T.M.; Smith, P.R.J.; Martina, L.J.; McNeill, C.L. \& Kendall, M.A. 2006. Occurrence of Sternaspis scutata (Polychaeta: Sternaspidae) in the English Channel. Cahiers de Biologie Marine, 47: 281-285. DOI

Wasson, K.; Zabin, C.J.; Bedinger, L.; Diaz, M.C. \& Pearse, J.S. 2001. Biological invasions of estuaries without international shipping: the importance of intraregional transport. Biological conservation, 102(2): 143-153. D0I

Williams, R.J.; Griffiths, F.B.; Van der Wal, E.J. \& Kelly, J. 1988. Cargo vessel ballast water as a vector for the transport of non-indigenous marine species. Estuarine, Coastal and Shelf Science, 26(4), 409-420.

Winston, J. 2012. Dispersal in marine organisms without a pelagic larval phase. Integrative and Comparative Biology, 52(4): 447-57. D0I

Zhadan, A.E.; Tzetlin, A.B. \& Salazar-Vallejo, S.I. 2017. Sternaspidae (Annelida, Sedentaria) from Vietnam with description of three new species and clarification of some morpho logical features. Zootaxa, 4226: 75-92. D01 